\title{
PENGARUH PERKEMBANGAN IPTEK TERHADAP PERMASALAHAN HAKI
}

\author{
Munsharif Abdul Chalim \\ Fakultas Hukum Universitas Islam Sultan Agung Semarang \\ E-mail: rierief@ymail.com
}

\begin{abstract}
Intellectual Property Rights' issues are growing problems in accordance with the development of science and technology. As examples of developments in biotechnology with the technology of genetic engineering led to the birth of the need to protect the results of biotechnology engineering. In developed countries Intellectual Property Rights has become part of everyday society, so that science and technology development in the country are always oriented to the protection of Intellectual Property Rights. Excellence in aspects of trade can be owned by developed countries because one of them is determined by the comparative advantage of the ability of science and technology that is related to the field of intellectual property rights.
\end{abstract}

Keywords: IPRs, law protection, economic benefit

\begin{abstract}
Abstrak
Masalah Hak Atas Kekayaan Intelektual adalah masalah yang berkembang sesuai dengan perkembangan ilmu pengetahuan dan teknologi. Sebagai contoh perkembangan bioteknologi dengan teknologi rekayasa genetika menyebabkan lahirnya kebutuhan untuk melindungi hasil rekayasa bioteknologi. Di negara maju Hak atas Kekayaan Intelektual telah menjadi bagian dari masyarakat sehari-hari, sehingga ilmu pengetahuan dan teknologi pembangunan di negeri ini selalu berorientasi pada perlindungan Hak Kekayaan Intelektual. Keunggulan dalam aspek perdagangan dapat dimiliki oleh negara maju karena salah satunya ditentukan oleh keunggulan komparatif dari kemampuan ilmu pengetahuan dan teknologi yang berhubungan dengan bidang hak kekayaan intelektual.
\end{abstract}

Kata Kunci: HaKI, perlindungan hukum, manfaat ekonomi

\section{Pendahuluan}

Hak atas Kekayaan Intelektual merupakan hak atas suatu karya cipta, baik karya seni, teknologi, atau buah pikiran; yang bersifat given dan inheren pada pencipta karya tesebut serta tidak dapat dipungkiri keberadaannya. Kata "intelektual" tercermin bahwa obyek kekayaan intelektual tersebut adalah kecerdasan, daya pikir, atau produk pemikiran manusia (the Creations of the Human Mind). Hak Kekayaan Intelektual (HaKI) adalah hak eksklusif yang diberikan kepada seseorang atau sekelompok orang atas karya ciptanya. Secara sederhana HaKI mencakup Hak Cipta, Hak Paten Dan Hak Merk. Namun jika dilihat lebih rinci HaKI merupakan bagian dari benda, yaitu benda tidak berwujud (benda imateriil). Hak Atas Kekayaan Intelektual (HaKI) termasuk dalam bagian hak atas benda tak berwujud (seperti Paten, merek, dan hak cipta).
Bila kita menengok ke belakang sejarah lahirnya Hak atas Kekayaan Intelektual, tenyata hak ini masih belum lama memperoleh perlindungan hukum, baik pengaturannya di negara-negara maju maupun di negara-negara berkembang. Baik hak cipta (copyright), hak atas merek, paten, desain, dan model maupun hak yang tidak berwujud (immateriil) lainnya, perlindungan hukumnya belum lama diakui dibandingkan dengan hak yang menurut hukum dikenal atas sesuatu benda yang berwujud.

Kreativitas dan inovasi teknologi sebagaimana peningkatan ekonomi sangat dibutuhkan bagi pertumbuhan masyarakat dan pengembangan industri. Melalui kreasi dan inovasi teknologi mendatangkan kemakmuran pertumbuhan ekonomi bagi kehidupan masyarakat. Sebagai contoh dalam rangka pengembangan teknologi di bidang piranti lunak (software) komputer atau teknologi informasi yang baru 
diperlukan biaya, waktu dan tenaga kerja yang membutuhkan keahlian tertentu. ${ }^{1}$ Pada mulanya hak cipta (copyright) tidak diakui sebagai suatu hak tersendiri, sebab ciptaan spiritual tidak dilihat sebagai terpisah dari obyek materiil yang di dalamnya ciptaan tersebut terwujud. Namun dalam perkembangannya mulai timbul pengertian, bahwa pencipta harus dipandang sebagai yang berhak atas karyanya sendiri. Sebagai pencipta mempunyai suatu hak alamiah (natural right) atas apa yang telah diciptakannya itu, termasuk hak untuk menjual naskahnya kepada salah satu penerbit untuk jangka waktu tertentu. Untuk sementara waktu penerbit diberi hak monopoli untuk menyelenggarakan penerbitan, dan setelah itu pihak pengarang (author) dapat menjual ciptaannya itu kepada penerbit lain.

Hak Cipta adalah hak khusus bagi pencipta untuk mengumumkan atau memperbanyak ciptaannya. Termasuk ciptaan yang dilindungi adalah ciptaan dalam bidang ilmu pengetahuan, sastra dan seni. Berdasarkan Undang-Undang Nomor 19 Tahun 2002 Tentang Hak Cipta: Hak Cipta adalah hak eksklusif bagi Pencipta atau penerima hak untuk mengumumkan atau memperbanyak ciptaannya atau memberikan izin untuk itu dengan tidak mengurangi pembatasan-pembatasan menurut peraturan perundang-undangan yang berlaku. Hak cipta diberikan terhadap ciptaan dalam ruang lingkup bidang ilmu pengetahuan, kesenian, dan kesusasteraan. Hak cipta hanya diberikan secara eksklusif kepada pencipta, yaitu "seorang atau beberapa orang secara bersama-sama yang atas inspirasinya lahir suatu ciptaan berdasarkan pikiran, imajinasi, kecekatan, keterampilan atau keahlian yang dituangkan dalam bentuk yang khas dan bersifat pribadi". ${ }^{2}$

\footnotetext{
Suyud Margono; 2010, Hukum Hak Cipta Indonesia, Bogor: Ghalia Indonesia, hlm. 3

Lihat dan bandingkan dengan Eddy Damian, "Pengaturan dan Pengertian Hak Cipta Sebagai Hak Kekayaan Intelektual”, Majalah Hukum Pro Justitia Tahun XIX No. 3 Juli 2001 FH Unpar Bandung, hlm. 3-20; lihat pula Devi Rahayu, "Perlindungan Hukum terhadap Hak Clpta Motif Batik Tanjungbumi Madura", Jurnal Mimbar Hukum Vol. 23 No. 1 Februari 2011 FH UGM Yogyakarta, hlm. 115-131.
}

Menurut Megan Richarson, keuntungan ekonomi (economic benefit) dari Hak Cipta, dengan mempertimbangkan beberapa hal berikut. Pertama, wheather material incentive provided by copyright are relevant to the innovative process behind copyright works and others subject matter; kedua, wheather given that we import more copyright material than we export, Australia is a net loser from a copyright system that rewards innovation; dan ketiga, weaather the cost associated with the granting proprietary right over information outweigh the benefit of copyright. ${ }^{3}$

Hak cipta memerlukan perlindungan hukum karena dilandasi oleh beberapa pemikiranpemikiran. Pertama, tidak semua orang memiliki kemampuan menemukan sesuatu yang baru (kreativitas) dan diterima oleh umum (patent), seperti karya dalam bidang ilmu pengetahuan dan teknologi, bioteknologi, kesusastraan, industri, karya seni, merek dagang, serta karya cipta atas rekaman suara dan lain-lain; kedua, tidak semua orang memiliki talenta (bakat dan keterampilan) dalam suatu bidang tertentu yang hasil ciptaannya (copyright) banyak diminati dan bermanfaat untuk khalayak ramai; dan ketiga, tidak semua orang memilki banyak waktu, tenaga dan biaya untuk menemukan (patent) atau menciptakan (copyright) karya yang hasilnya bermanfaat untuk kepentingan umum.

Perlindungan terhadap hak kekayaan intelektual berujuan untuk memberikan perlindungan atas hak cipta dan untuk mendukung serta memberikan penghargaan atas buah kreativitas. Perlindungan ini diberikan agar tumbuh inovasi-inovasi baru baik dibidang perindustrian maupun seni dan ilmu pengetahuan. Adanya perlindungan terhadap hak kekayaan intelektual juga menjadi suatu aset yang bernilai karena memberikan hak-hak keekonomian yang besar. Adanya hak kekayaan intelektual ini bahkan dapat menjadi suatu katalis bagi partumbuhan perekonomian suatu negara. Oleh karena

Megan Richardson, et.al., 2000, The Benefits and cost of Copyrights: an Economic Perspective, Discussion Papers for The Centre for Copyright Studies Ltd, Published in June 2000, hlm. 7 
sifatnya yang universal, perlindungan hak kekayaan intelektual haruslah didukung dan diakui oleh negara-negara di dunia. ${ }^{4}$

Di samping hak cipta, dalam hak atas kekayan intelektual mencakup juga hak atas merek, yang terbagi atas hak atas merek dagang, hak atas merek jasa, hak atas merek kolektif. Merek dagang adalah merek yang digunakan pada barang yang diperdagangkan oleh seseorang atau beberapa orang secara bersamasama atau badan hukum untuk membedakan dengan barang-barang sejenis lainnya, dan hak atas merek jasa yaitu merek yang digunakan pada jasa yang diperdagangkan oleh seseorang atau beberapa orang secara bersama-sama atau badan hukum untuk membedakan dengan jasajasa sejenis lainnya. Serta hak atas merek kolektif adalah merek yang digunakan pada barang atau jasa dengan karakteristik yang sama yang diperdagangkan oleh beberapa orang atau badan hukum secara bersama-sama untuk membedakan dengan barang atau jasa sejenis lainnya. ${ }^{5}$ Hak atas merek adalah hak khusus yang diberikan negara kepada pemilik merek yang terdaftar dalam Daftar Umum Merek untuk jangka waktu tertentu, menggunakan sendiri merek tersebut atau memberi izin kepada seseorang atau beberapa orang secara bersama-sama atau badan hukum untuk menggunakannya. ${ }^{6}$

Permasalahan HaKI selalu dibarengi dengan perkembangan ilmu pengetahuan dan teknologi. Kita maklumi bahwa Ilmu Pengetahuan dan Teknologi merupakan suatu sarana yang sangat penting bagi negara-negara berkembang. Seiring berjalannya waktu, IImu pengetahuan dan teknologi (iptek) telah berkem-

Lihat dan bandingkan dengan tulisan Endang Purwaningsih, "Paten sebagai Konstruksi Hukum Perlindungan Terhadap Invensi Bidang Teknologi dan Industri", Jurnal Hukum Pro Justitia Vol. 24 No. 2 April 2006 FH Unpar Bandung, hlm. 129-135

5 Lihat perkembangan pengertian merek pada Tomi Suryo Utomo, "Perkembangan Definisi Merek Pasca Perjanjian TRIPs dan Kemungkinan Perluasan Definisi Merek di Indonesia", Jurnal Ilmiah Hukum dan Dinamika Masyarakat, Edisi Khusus Agustus 2009 FH Untag Semarang, hlm. 1-11.

6 Lihat mengenai hal ini dalam Agung Sujatmiko, "Aspek Yuridis Lisensi Merek dan Persaingan Usaha", Jurnal Hukum Pro Justitia Vol. 26 No. 2 April 2008 FH Unpar Bandung, hlm. 93-110. bang dengan pesat mengikuti perkembangn jaman. Di jaman modern ini iptek tidak diragukan lagi dalam kegunaannya, dan iptek telah banyak membantu manusia dalam menyelesaikan pekerjaan sehari-hari. Kecenderungan era globalisasi pada sektor ilmu pengetahuan dan teknologi serta ekonomi tidak dapat di hinderkan, dan hal ini tanpa disadari telah mempengaruhi kehidupan manusia. Masyarakat yang memiliki ilmu pengetahuan dan teknologi tinggi biasanya sedah memiliki prasarana dan pranata sosial yang memadai untuk dikembang-kannya iptek dalamkaitannya dengan amsakah-masalah yang dipengaruhinya. Sudah barang tentu HaKI merupakan suatu hak yang berada di dalam ruang lingkup yang berkaitan dengan kehidupan ilmu pengetahuan dan teknologi, artinya HaKI merupakan hak yang berasal dari karya, karsa dan cipta manusia karena lahir dari kemampuan intelektualitas manusia, dan merupakan hasil kegiatan kreatif suatu kemampuan daya pikir manusia yang memerlukan sarana ilmu pengetahuan dan teknologi. Esensi yang terpenting dari setiap bagian HaKI adalah adanya suatu ciptaan tertentu yang memerlukan perkembangan ilmu pengetahuan dan teknologi dan dibarengi dengan upaya perlindungan akan ciptaannya itu. Sehingga jelas bahwa permasalahan HaKI merupakan permasalahan yang terus berkembang sesuai dengan perkembangan ilmu pengetahuan dan teknologi.

Permasalahan HaKI ini sudah menjadi perhatian bagi kebanyakan negara, termasuk Indonesia, terutama setelah terjadinya revolusi industri di Inggris dan revolusi politik di Perncis pada abad XVIII. Akibat revolusi tersebut banyak memberikan dorongan bagi perkembangan asas-asas dan obyek perkembangan hukum hak milik atas kekayaan intelektual. Suatu misal dengan berkembangnya teknologi pembuatan 'microchips' atau 'semi-conductor', maka berkembang pula obyek-obyek yang harus dilindungi di bidang HaKl, sehingga lahirlah suatu hak yang disebut hak topography. Damikian juga dengan perkembangan bioteknologi, tentunya akan melahirkan suatu kebutuhan untuk melindungi hasil rekayasa bioteknologi, misalnya perlindungan terhadap varietas tumbuhan, 
sehingga lahir pula ketentuan-ketentuan untuk mengaturnya.

Hak atas Kekayaan Intelektual merupakan hak kebendaan yang munculnya bukan karena secara alamiah sebagaimana hak kebendaan lainnya, namun keberadaannya telah melengkapi konsepsi mengenai hak milik dalam hukum perdata Indonesia. Perkara HaKI dapat timbul apabila terdapat perselisihan (dispute), artinya ada pelanggaran HaKI, baik secara perdata maupun secara pidana, juga timbulnya karena pelaksanaan proses administrasi, yang berakibat adanya penolakan HaKI oleh Kantor Hak Cipta, Paten, dan Merek. Menurut Priyatna Abdurrasyid, Alternative Dispute Resolution (ADR), the acronym that has been adopted as a set of practices that aim; first, to permit (legal) disputes to be resolved outsides the court for the benefit of all disputes; second, to reduced the cost of conventional litigation and the delays to which it is ordinarily subjected; and third, to prevent (legal) disputes that would otherwise likely be brought to court. ${ }^{7}$

Mendasarkan pada hal tersebut, perkara HaKI dapat digolongkan menjadi perkara perdata, perkara pidana dan perkara administrasi. Selanjutnya kewenangan untuk menangani perkara-perkara tersebut menjadi kompetensi badan peradilan. Sehingga dalam hal ini dapat ditegaskan bahwa proses penciptaan hak milik intelektual itu, disamping dipengaruhi adanya bakat, tenaga, waktu, dan biaya, juga tidak bisa terlepas adanya pengaruh ilmu pengetahuan dan teknologi. Dalam era globalisasi ini permasalahan HaKI semakin terasa lebih kompleks, di mana sudah tidak murni lagi hanya bidang HaKI semata, namun sudah mulai tekait dengan bidang ekonomi antar negara maju dengan dengan berkembang, yang kesemuanya tidak bisa terlepas dari peran ilmu pengetahuan dan teknologi (iptek).

Hak atas kekayaan intelektual mempunyai pengertian yang sangat luas, yang mencakup antara lain karya kesusasteraan, artistik maupun ilmu pengetahuan, pertunjukan seni,

Priyatna Abdurrasyid, 2001, The Arbitration Law of Indonesia, dalam Prospek dan Pelaksanaan Arbitrase di Indonesia, Bandung: Citra Aditya Bakti, hlm. 86 penyiaran audio visual, penemuan dalam segala bidang usaha manusia, penemuan ilmiah, desain industri, merek dagang dan perlindungan terhadap persaingan curang. Di era globalisasi sekarang ini, hak atas kekayaan intelektual merupakan suatu hak yang berada dalam ruang lingkup bidang ilmu pengetahuan dan teknologi. Dari uraian di atas, permasalahan yang hendak dibahas pada tulisan ini adalah tentang pengaruh iptek terhadap permasahan HaKI bagi suatu negara dalam menjaga keunggulan industri dan perdagangannya.

\section{Pembahasan}

HaKI adalah instrumen hukum yang memberikan perlindungan hak pada seseorang atas segala hasil kreativitas dan perwujudan karya intelektual dan membrikan hak kepada pemilik hak untuk menikmati keuntungan ekonomi dari kepemilikan hak tersebut. Hasil karya intelektual tesebut dalam praktek dapat berwujud ciptaan di bidang seni, sastra, merek, penemuan di bidang teknologi tertentu dan lain sebagainya. Melalui perlindungan ini para pemilik hak berhak untuk menggunakan, memperbanyak, mengumumkan, memberikan ijin kepada pihak lain untuk memanfaatkan haknya tersebut melalui lisensi atau pengalihan dan termasuk untuk melarang pihak lain untuk menggunakan, memperbanyak dan/atau mengumumkan hasil karya intelektual tersebut. Bagi bangsa Indonesia, perlindungan hukum HaKI merupakan perkembangan yang baru, tetapi bagi negara-negara maju telah dikenal karena pandangan akan prinsip manfaat ekonomi atau nilai ekonomi (economic value) yang cukup besar bagi pendapatan negara. ${ }^{8}$ )

HaKI memberikan hak monopoli kepada pemilik hak dengan tetap menjunjung tinggi pembatasan-pembatasan yang meungkin diberlakukan berdasarkan peraturan perundang-undangan yang berlaku. Hak cipta memberikan perlindungan tehadap karya musik, karya sastra, drama dan karya artistik, termasuk juga rekaman suara, penyiaran film, dan program

8 Bambang Kesowo, Pengantar Umum Mengenai Hak atas Kekayaan Intelektual (HaKI), Jakarta: Sekretariat Negara RI, (terbit tanpa tahun), hlm. 1 
pertelevisian. Dasar pemikiran diberikannya kepada seorang atau individu untuk perlindung-an hukum terhadap "ciptaan" bermula dari teori yang tidak lepas dari dominasi pemikiran madzhab atau doktrin hukum alam yang menekankan pada faktor manusia dan penggunaan akal seperti yang dikenal dalam sistem hukum sipil (civil law system) yang merupakan sistem hukum umum yang dipakai di Indonesia. ${ }^{9}$ Hak cipta merupakan hak eksklusif bagi Pencipta atau Pemegang Hak Cipta untuk mengumumkan atau memperbanyak Ciptaaannya, yang timbul secara otomatis setelah suatu Ciptaan dilahirkan tanpa mengurangi pembatasan menurut peraturan perundang-undangan yang berlaku (Pasal 1 angka 1 UU No. 19 Tahun 2002 tentang Hak Cipta). Di samping hak cipta, ada pula hak atas merek yang pada dasarnya memberikan perlindungan atas tanda-anda berupa huruf, kata, angka, dan lain sebagainya, yang digunakan dalam kegiatan perdagangan barang atau jasa.

Terdapat bidang yang khusus dalam hak atas kekayaan intelektual yang berkenaan dengan bidang industri dan pengetahuan, yang lazim disebut sebagai hak atas kekayaan industri (industrial property). Sejauh ini upaya sosialisasi penghargaan atas Hak atas Kekayaan Intelektual (HaKI) telah dilakukan, namun upa-ya tersebut tempaknya belum cukup berhasil. Hal ini karena konsep dan perlunya HaKI belum dipahami secara benar di kalangan masyarakat, dan kurang optimalnya upaya penegakannya, baik oleh pemilik HaKI sendiri maupun oleh aparat penegak hukum, serta tidak adanya kesamaan pandangan dan pengertian mengenai pentingnya perlindungan $\mathrm{HaKI}$ di kalangan pemilik HaKI.

Kebijakan dalam Perlindungan HaKI di bidang hukum telah diatur dalam Peraturan Perundang-undangan maupun Konvensi-konven-si International. HaKI menjadi sangat penting untuk menggairahkan laju perekonomian dunia yang pada akhirnya membawa kesejahteraan umat manusia. Meskipun terus ada upaya pengurangan angka tarif dan kuota secara gradual dalam rangka mempercepat terbentuknya per-

9 Satjipto Rahardjo; 1991, Ilmu Hukum, Bandung: Alumni, hlm. 292 dagangan bebas, jika produk impor barang dan jasa dibiarkan bebas diduplikasi secara ilegal, ini merupakan beban berat bagi pelaku perdagangan internaional. ${ }^{10}$ Pada saat ini Indonesia telah memiliki perangkat peraturan perundangundangan di bidang hak atas kekayaan intelektual yang cukup memadai dan tidak bertentangan dengan ketentuan sebagaimana yang dipersyaratkan dalam Persetujuan TRIPs. Pasal 7 Persetujuan TRIPs menyebutkan, perlindungan dan penegakan hukum HaKI bertujuan mendorong timbulnya inovasi, pengalihan dan dan penyebaran teknologi dan diperolehnya manfaat bersama antara penghsilan dan pengguna pengetahuan teknologi, dengan cara menciptakan kesejahteraan sosial dan ekonomi serta keseimbangan antara hak dan kewajiban. ${ }^{11}$

Prinsip-prinsip pokok persetujuan TRIPs, antara lain sebagai berikut. Pertama, menetapkan standar minimum untuk perlindungan dan penegakan hukum HaKl di negara-negara peserta. Dengan demikian, negara peserta bisa menetapkan standar yang lebih tinggi selama hal tersebut tidak bertentangan dengan persetujuan TRIPs. Kedua, negara-negara pe-serta diharuskan memberikan perlindungan $\mathrm{Ha}-\mathrm{KI}$ yang sama kepada warga negaranya sendiri dan warga negara peserta lainnya. Adapun hak yang diberikan kepada warga negaranya, juga harus diberikan pada warga negara peserta lain. ${ }^{12}$

Peraturan perundang-undangan tentang HaKI di Indonesia terdiri dari Undang-undang No. 12 Tahun 1997 tentang Perubahan Undangundang No. 6 Tahun 1982 tentang Hak Cipta sebagaimana telah diubah dengan Undang-undang No. 7 tahun 1987 (UU Hak Cipta); Undang-undang No. 29 Tahun 2000 tentang Perlindungan Varietas Tanaman; Undang-undang No. 30 Tahun 2000 tentang Rahasia Dagang; 4. Undangundang No. 31 Tahun 2000 tentang Desain In-

10 Adrean Sutedi, op.cit, hlm. 6

11 Suyud Margono, op.cit, hlm. 5. Lihat lebih jelas pada Suparto Wijoyo, "GREAT SIGNIFICANCE" Hukum dalam Proses Alih Teknologi (Pendayagunaan Hukum sebagai Instruen Proses Alih Teknologi)", Majalah Hukum Pro Justitia Tahun XVI No. 3 Juli 1998 FH Unpar Bandung, hlm. 8-18

12 A. Zen Umar Purba, "Menyambut Millenium III: TRIPs, Dimensi HaKI dan Kesiapan Kita", Newsletter No.39, X (Desember 1999), hlm. 2 
dustri; Undang-undang No. 32 Tahun 2000 tentang Desain Tata Letak Sirkuit Terpadu; Undang-undang No. 14 Tahun 2001 tentang Paten (UU Paten); dan Undang-undang No. 15 Tahun 2001 tentang Merek; Di Indonesia, sistem perlindungan merek telah dimulai sejak tahun 1961 , sistem perlindungan hak cipta dimulai sejak tahun 1982, sedangkan sistem paten baru dimulai sejak tahun 1991. Akhirnya pada tahun 2001, Undang-Undang Nomor 12 Tahun 1997 jis, Undang-Undang Nomor 7 Tahun 1987, UndangUndang Nomor 6 Tahun 1982 tersebut diubah dan disempurnakan serta diganti dengan Undang-Undang Nomor 19 Tahun 2002. ${ }^{13}$

Rahasia dagang adalah informasi yang tidak diketahui oleh umum di bidang teknologi dan/atau bisnis, mempunyai nilai ekonomi karena berguna dalam kegiatan usaha, dan dijaga kerahasiaannya oleh pemilik Rahasia Dagang. Rahasia dagang dan jenis-jenis informasi rahasia lainnya yang memiliki nilai komersil harus dilindungi dari pelanggaran atau kegiatan lainnya yang membuka rahasia praktek komersial. Namun langkah-langkah yang rasional harus ditempuh sebelumnya untuk melindungi informasi yang bersifat rahasia tersebut. Pengujian terhadap data yang diserahkan kepada pemerintah sebagai langkah memperoleh persetujuan untuk memasarkan produk farmasi atau pertanian yang memiliki komposisi baru juga harus dilindungi dari kecurangan perdagangan.

Desain industri adalah suatu kreasi tentang bentuk, konfigurasi, atau komposisi garis atau warna, atau garis dan warna, atau gabungan daripadanya yang berbentuk tiga dimensi atau dua dimensi yang memberikan kesan estetis dan dapat diwujudkan dalam pola tiga dimensi atau dua dimensi serta dapat dipakai untuk menghasilkan suatu produk, barang, komoditas industri, atau kerajinan tangan. Desain industri diterapkan pada berbagai jenis produk industri dan kerajinan; dari instrumen teknis dan medis, jam tangan, perhiasan, dan bendabenda mewah lainnya; dari peralatan rumah tangga dan peralatan elektronik ke kendaraan dan struktur arsitektural; dari desain tekstil

13 Adrian Sutedi, op.cit, hlm. 5 hingga barang-barang hiburan. Agar terlindungi oleh hukum nasional, desain industri harus terlihat kasat mata. Hal ini berarti desain industri pada prinsipnya merupakan suatu aspek estetis yang alami, dan tidak melindungi fitur teknis atas benda yang diaplikasikan. Di Indonesia Desain Industri di-atur dalam UU No. 31 Tahun 2000 Tentang Desain Industri.

Sirkuit terpadu adalah suatu produk dalam bentuk jadi atau setengah jadi, yang di dalamnya terdapat berbagai elemen dan sekurang-kurangnya satu dari elemen tersebut adalah elemen aktif, yang sebagian atau seluruhnya saling berkaitan serta dibentuk secara terpadu di dalam sebuah bahan semi konduktor yang dimaksudkan untuk menghasilkan fungsi elekronik. Desain tata letak merupakan suatu kreasi berupa rancangan peletakan tiga dimensi dari berbagai elemen, sekurang-kurangnya satu dari elemen tersebut adalah elemen aktif, serta sebagian atau semua interkoneksi dalam suatu sirkuit terpadu dan peletakan tiga dimensi tersebut dimaksudkan untuk persiapan pembuatan sirkuit terpadu. Desain Tata Letak Sirkuit Terpadu di Indonesia diatur dalam UU No. 31 Tahun 2000 Tentang Desain Tata Letak Sirkuit Terpadu. ${ }^{14}$

Indikasi Geografis merupakan suatu tanda yang digunakan pada barang-barang yang memiliki keaslian geografis yang spesifik dan memiliki kualitas atau reputasi berdasar tempat asalnya itu. Pada umumnya, Indikasi Geografis merupakan nama tempat dari asal ba-rang-barang tersebut. Produk-produk pertanian biasanya memiliki kualitas yang terbentuk dari tempat produksinya dan dipengaruhi oleh fak-torfaktor lokal yang spesifik, seperti iklim dan tanah. Berfungsinya suatu tanda sebagai indikasi geografis merupakan masalah hukum nasional dan persepsi konsumen. Pengertian Indikasi Geografis dapat dikemukakan sebagai berikut. Pertama, indikasi Geografis dapat berwujud

14 Lihat pembahasan mengenai tata letak sirkuit terpadu pada Hj. Soendari Kabat, "Aspek Hukum Hak Atas Desain Tata Letak Sirkuit Terpadu", Jurnal Hukum Pro Justitia Vol. XXIII No. 2 April 2005 FH Unpar Bandung, hlm. 65-76; Catharina Ria Budiningsih, "Hak Desain Industri Vs Perlindungan Hukum pada Motif-motif Tradisional”, Jurnal Hukum Pro Justitia Tahun XX No. 1 Januari 2003 FH Unpar Bandung, hlm. 82-87 
nama geografis atau tanda-tanda lain selama tanda tersebut bisa mengidentifikasikan secara jelas tempat asal produk tersebut; kedua, indikasi Geografis menandakan asal tempat suatu barang, dan mempunyai arti yang luas dari sekedar nama tempat, sehingga dapat juga melindungi simbol; dan ketiga, indikasi Geografis menunjuk kepada reputasi produk yang terkait, menunjuk kepada lingkungan geografis sebagai faktor utama, dan kuat karena tidak hanya melindungi konsumen, tetapi juga melindungi produsen. ${ }^{15}$

Hal yang menarik untuk dicatat dari rezim Indikasi Geografis adalah bahwa perlindungan terkuatnya memungkinkan suatu produk untuk mendapat perlindungan secara terusmenerus. Pada tingkat terendah, sebagaimana dipakai negara-negara istilah Indications of Source atau Sertification Marks, perlindungan diberikan bagi konsumen agar mereka tidak dibingungkan, seperti halnya Merek. Akan tetapi perlindungan optimal dari rezim ini ternyata juga bisa berpihak kepada kelompok produsennya. ${ }^{16}$

Sejalan dengan perubahan berbagai undang-undang tersebut di atas, Indonesia juga telah meratifikasi 5 konvensi internasional di bidang hak kekayaan intelektual, yaitu sebagai berikut : Paris Convention for the Protection of Industrial Property dan Convention Establishing the World Intellectual Property Organization (Keputusan Presiden No. 15 tahun 1997 tentang Perubahan atas Keputusan Presiden No. 24 Tahun 1979); Patent Cooperation Treaty (PCT) and Regulation under the PCT (Keputusan Presiden No. 16 Tahun 1997); Trademark Law Treaty (Keputusan Preiden No. 17 Tahun 1997); Berne Convention for the Protection of Lite-

15 Sergio Escudero, 2001, International Protection of Geographical indications and Developing Countries, Trade Related Agenda, Developing and Equity working paper, July 2001, South Centre, hlm. 5. Lihat juga Suradiyanto, "Perlindungan Hukum terhadap Produsen Ditinjau dari Segi Indikasi Geografis: Studi Kasus Produk Sarung Samarinda", Jurnal Hukum Pro Justitia, Vol. 24 No. 2 April 2006 FH Unpar Bandung, hlm. 182-189; Shidarta, "Beberapa Catatan tentang Pengaturan Indikasi Geografis dan Indikasi Asal dalam Hukum Merek Indonesia", Majalah HUkum Pro Justitia Tahun XVI No. 3 Juli 1998 FH Unpar Bandung, hlm.94-101.

16 Adrean Sutedi, op.cit, hlm. 170 rary and Artisctic Works (Keputusan Presiden No. 18 Tahun 1997); WIPO Copyright Treaty (Keputusan Presiden No. 19 Tahun 1997). Administrasi Hak atas Kekayaan Intelektual Secara institusional, pada saat ini telah ada Direktorat Jendral Hak Kekayaan Intelektual yang tugas dan fungsi utamanya adalah menyelenggarakan administrasi hak cipta paten, merek, desain industri, dan desain tata letak sirkuit terpadu. Direktorat Jenderal Hak Kekayaan Intelektual semula disebut Direktorat Jenderal Hak Cipta, Paten dan Merek) dibentuk pada tahun 1998. Direktorat Jendral Hak Kekayaan Intelektual sebagaimana yang diharapkan oleh masyarakat, berasal dari dunia industri dan perdagangan, serta institusi yang bergerak di bidang penelitian dan pengembangan. Direktorat Jendral Ha$\mathrm{KI}$ merupakan institusi yang relatif masih mu$\mathrm{da} /$ baru, oleh sebab itu, dapat dimaklumi seandainya dalam pelaksanaan tugasnya, masih dijumpai berbagai macam kendala.

HaKI telah menjadi salah satu isu penting dalam praktek pergaulan internasional yang selalu diperhatikan oleh kalangan negara-negara maju di dalam melakukan hubungan perdagangan dan hubungan ekonomi lainnya. Hal ini mengandung pengertian, bahwa di negara maju HaKI telah menjadi bagian keseharian masyarakatnya, sehingga perkembangan ilmu pengetahuan dan teknologi di negara tersebut selalu berorientasi untuk mendapatkan perlindungan atas HaKI. Banyaknya HaKI yang dihasilkan menjadikan pertumbuhan industri nasional di negara tersebut cukup tinggi dan aspek perdagangan menjadi bgian utama. Keunggulan dalam aspek perdagangan dapat dimilki oleh negara maju, karena salah satu diantaranya ditentukan oleh keunggulan komparatif berupa kemampuan ilmu pegetahuan dan teknologi yang sangat berkaitan dengan bidang kekayaan intelektual. Dapat dikatakan di sini, bahwa kekayaan intelektual merupakan salah satu bagian yang sangat strategis bagi suatu negara dalam mengkokohkan kehidupan ekonomi pada era perdagangan internasional dengan melalui ilmu pengetahuan dan teknologi yang dimiliki-nya. Era globalisasi yang sangat identik dengan free market, free competition dan transporta-tion 
memberikan dampak yang cukup besar terhadap perlindungan HaKi. ${ }^{17}$ Dalam kaitannya dengan negara Amerika Serikat, saat ini status Indonesia masih tetap sebagai negara dengan status 'Priority Watch List', sehingga dapat memperlemah negosiasi antar pihak yang bersangkutan. Situasi seperti ini memberikan tantangan kepada Indonesia, di mana Indonesia harus berusaha untuk memberikan perlindungan yang memadai atas Hak atas Kekayaan Intelektual (HaKI), sehingga dapat tercipta suatu persaingan yang sehat untuk dapat memberikan kepercayaan kepada investor asing dalam menanamkan modalnya di Indonesia.

Apabila terdapat perlindungan yang memadai atas HaKI di Indonesia, maka sudah barang tentu dengan meningkatnya kegiatan investasi asing yang sedikit banyak melibatkan proses transfer teknologi yang dilindungi oleh HaKI akan terlaksana dengan baik. Mengingat hal tersebut, tanpa usaha sosialisasi di berbagai lapisan masyarakat kesadaran akan keberhargaan HaKI tidak akan tercipta. Sehingga sosialisasi HaKI harus terus dilakukan pada semua kalangan terkait, seperti aparat penegak hukum, pelajar, masyarakat pemakai, para pencipta dan yang tak kalah pentingnya adalah kalangan pers, karena dengan melalui jurnalis upaya kesadaran akan pentingnya HaKI relatif lebih mudah terwujud.

Kiranya pemilik hak perlu melakukan langkah-langkah non-legal untuk menegaskan kepemilikan haknya, dan juga menegaskan kepada pihak lain, bahwa mereka akan mengambil tindakan yang tegas terhadap segala upaya penggunaan atau pemanfaatan secara tidak sah atas haknya tersebut. Harus kita sadari, bahwa dengan kemajuan ilmu pengetahuan dan teknologi, sampai sekarang keberadaan produkproduk yang melanggar HaKl, khususnya merek dan hak cipta dengan sangat mudah bisa kita dapatkan, baik di tempat perbelanjaan kelas bawah maupun dipusat perbelanjaan me-wah. Namun yang ada baik pemegang merek maupun

17 Lihat mengenai mekanisme dalam perdagangan internasional pada A.F. Elly Erawaty, "Sistem dan Mekanisme Perdagangan Internasional", Majalah Hukum Pro Justitia Tahun XII No. 4 Oktober 1994 FH Unpar Bandung, hlm. 87-112. hak cipta tidak mendapatkan respon yang baik atas penegakan hukum yang ada, dan karena hal ini menyangkut masalah investasi, khususnya di Indonesia, maka tentunya akan menjadi sorotan dunia internasional dalam penegakkan HaKI di Indonesia. ${ }^{18}$

Apabila kita melihat ke belakang sejarah perkembangan HaKI, bahwa di negara barat penghargaan atas kekayaan intelektual sudah sangat lama diterapkan dalam budaya mereka, yang kemudian diterjemahkan dalam perundang-undangan. HaKI bagi masyarakat barat bukanlah sekedar perangkat hukum yang digunakan hanya untuk perlindungan terhadap hasil karya intelektual seseorang, akan tetapi dipakai juga sebagai alat strategi usaha, di mana hasil penemuan kekayaan intelektual dikomersialkan yang memungkinkan pencipta atau penemu tersebut dapat mengeksploitasi hasil penemuan atau ciptaannya secara ekonomi.

Memasuki milenium baru, hak intelektual telah menjadi isu yang sangat penting, yang selalu mendapat perhatian, baik dalam forum nasional maupun internasional. Dimasukkannya TRIPs dalam paket Persetujuan WTO sejak tahun 1994 menandakan dimulainya era baru perkembangan ilmu pengetahuan dan teknologi yang diterapkan pada HaKI di seluruh dunia. Pada saat ini permasalahan HaKl tidak dapat dilepaskan dari dunia ilmu pengetahuan dan teknologi yang diterapkan dalam segala kegiatan, termasuk kegiatan perdagangan dan investasi. Sehingga jelaslah di sini, bahwa permasalahan HaKI dalam dunia perdagangan dan investasi telah dimulainya era baru pembangunan

18 Lihat dan bandingkan dengan tulisan Agung Sujatmiko, "Politik Hukum Perlindungan Hak Merek", Majalah Hukum Pro Justitia tahun XIX No. 1 Januari 2001 FH Unpar Bandung, hlm. 39-50; Agung Sujatmiko, Perlindungan Hukum Hak Merek Secara Represif", Majalah Hukum Pro Justitia Tahun XIX No. 3 Juli 2001 FH Unpar Bandung, hlm. 75-85; Agung Sujatmiko, "Prinsip Hukum Kontrak dalam Lisensi Merek", Jurnal Mimbar Hukum Vol. 20 No. 2 Juni 2008 FH UGM Yogyakarta, hlm. 251266; dan Agung Sujatmiko, "Peran dan Arti Penting Perjanjian Lisensi dalam Melindungi Merek Terkenal", Jurnal Mimbar Hukum Vol. 22 No. 1 Februari 2010 FH UGM Yogyakarta, hlm. 114-126. 
ekonomi yang dipengaruhi oleh ilmu pengetahuan dan teknologi. ${ }^{19}$

Ruang lingkup HaKI tidak bisa terlepas dari suatu hak yang berada dalam kehidupan ilmu pengetahuan dan teknologi, di mana sifat kepemilikannya bukan terhadap barangnya melainkan terhadap hak kemampuan intelektual penciptanya atau penemunya. HaKI baru bisa dimiliki seseorang apabila kemampuan intelektual manusia itu telah membentuk sesuatu yang bisa dilihat, didengar, dibaca maupun digunakan secara praktis. HaKI merupakan hak yang berasal dari karya, karsa, cipta manusia, karena lahir dari kemampuan intelektualitas manusia dan merupakan hasil kegiatan kreatif suatu kemampuan daya pikir manusia yang diekspresikan kepada khalayak umum dalam berbagai bentuknya. Sehingga permasalahan HaKI merupakan permasalahan yang terus berkembang sesuai dengan perkembangan ilmu pengetahuan dan teknologi. Perkembangannya tersebut hanya menyangkut tuntutan agar dapat dikuasainya atau dipergunakannya hal-hal yang telah ditemukan atau telah diciptakan, dengan kemampuan tenaga dan intelektual manusia. Permasalahan HaKI menjadi semakin berkembang dengan maraknya pembajakan (piracy) terhadap produk yang dianggap laku di pasaran domestik maupun pasaran inernasional.

Menurut Carlos Corriea, seorang peneliti Third World Network, bahwa penegakan HaKI sebetulnya bukan hanya bermaksud mengurangi pembajakan seperti yang disebutkan di atas, tetapi sekaligus merupakan kebijakan yang melakukan proteksi atas teknologi dan memperkuat pembagian kerja internasional baru. Negara industri maju menjadi penghasil temuan, sementara negara berkembang menjadi pasar dari produk dan jasa yang dihasilkan. ${ }^{20}$

Maraknya pembajakan produk tersebut akan menyebabkan kemunduran perekonomian

19 Perkembangan ilmu dan teknologi pun tak luput dari upaya WTO melakukan pengaturan dalam lalu lintas perdagangan internasional. Lihat dalam Gunarto Suhardi, "Peran WTO dalam Pembentukan Peraturan Perdagangan Internasional", Jurnal Hukum Pro Justitia Vol. 25 No. 1 Januari 2007, FH Unpar Bandung, hlm. 23-29

20 Carlos M. Corriea, 2000, Intellectual Property Rights, the WTO and the Developing Countries: Third World Network, Penang. bagi sautu negara, sebagai contoh munculnya berbagai macam pembajakan software yang dapat menyebabkan kemunduran bagi perekonomian suatu negara. ${ }^{21}$ Celakanya lagi apabila suatu negara sudah tergantung terhadap software bajakan tesebut. Akibat lain adalah tertutupnya lapangan pekerjaan di sektor ekonomi bagi para pencari pekerja baru, yang menyebabkan stagnasi pertumbuhan ekonomi. Tentunya perusahaan-perusahaan Information Technology (IT) dunia akan enggan untuk menanam investasinya di negara yang banyak terjadi pembajakan software. Di sini diperlukan adanya kesadaran budaya masyarakat untuk menggunakan original software, dan harus ada sebuah kebijakan akan pentingnya perlindungan Hak Cipta Software tersebut.

Sebuah negara berkembang yang tinggi tingkat pembajakan softwarenya akan susah untuk menjadi negara maju di bidang ilmu pengetahuan dan teknologi, karena pondasi dasar ekonomi kreatifnya sangat lemah dalam hal perlindungan Hak atas Kekayaan Intelektualnya. Selain itu dengan tidak adanya sanksi yang tegas terhadap pembajakan software ini akan menyebabkan tingkat ketergantungan yang cukup memprihatinkan, karena terhentinya kreativitas dan inovasi masyarakat. Kiranya perlu dilakukan dua kebijakan yang tegas, yaitu mendukung sepenuhnya penegakan hukum di bidang produk teknologi (software), dan mendukung penuh penggunaan produk tersebut bersifat terbuka. ${ }^{22}$

Memasuki era globalisasi menyebabkan permasalahan HaKI semakain bertambah kompleks, permasalahannya bukan hanya sekedar HaKI semata, akan tetapi sudah terkait dengan bidang ekonomi antara negara maju dengan

21 Lihat dan baca tentang pengaruh pembajakan HaKI (Merek) terhadap perekonomian nasional pada Agung Sujatmiko, "Pembajakan Merek Merusak Pereknonomian Nasional”, Jurnal Hukum Pro Justitia Vol. 25 No. 3 Juli 2007 FH Unpar Bandung, hlm. 178-189 dan Didik Endro Purwoleksono, “Tindak Pidana di Bidang Merek”, Jurnal Yuridika Vol. 20 No. 4 Juli 2005 FH Unair Surabaya.

22 Salah satu sarana untuk memberantas pembajakan adalah dengan hukum pidana. Lihat dan baca Supanto, "Kebijakan Hukum Pidana dalam Penanggulangan Pembajakan Perangkat Lunak Komputer", Jurnal Mimbar Hukum Vol. 19 No. 3 Oktober 2007 FH UGM Yogyakarta, hlm. 351-364. 
negara berkembang. ${ }^{23} \mathrm{Hal}$ ini menunjukkan bahwa HaKI telah menjadi bagian terpenting suatu negara untuk menjaga keunggulan bidang industri teknologinya dan perdagangannya. Berkembangnya ilmu pengetahuan dan teknologi juga memberikan pengaruh yang besar terhadap permasalahan HaKI, sebagai contoh berkembangnya bidang bioteknologi, dengan adanya teknologi rekayasa genetika, yang menyebabkan lahirnya kebutuhan untuk melindungi hasil rekayasa bioteknologi tersebut, yang selanjutnya perlu dibarengi adanya sarana untuk mengaturnya.

Dari uraian di atas, jelaslah bahwa peranan HaKI dewasa ini sangatlah penting, yaitu sebagai alat persaingan dagang, terutama bagi negara maju agar tetap dapat menjaga posisinya untuk menguasai pasar internasional dengan produk barangnya; sebagai alat pendorong kemajuan iptek melalui inovasi-inovasi baru yang dapat diindustrikan; dan sebagai alat peningkatan kesejahteraan perekonomian masyarakat, khususnya para peneliti yang mempunyai temuan-temuan baru. Jadi pengaruh pekembangan ilmu pengetahuan dan teknologi (iptek) sangat besar sekali terhadap permasalahan $\mathrm{Ha}$ $\mathrm{KI}$, terutama bagi negara maju, mengingat perkembangan ilmu pengetahuan dan teknologi itu sendiri akan selalu dibarengi dengan adanya perlindungan atas hasil atau produk-produk dari ilmu pengetahuan dan teknologi, yang berupa Hak atas Kekakayaan Intelektual (HaKI). Meningkatnya perkembangan ilmu pengetahuan dan teknologi, sudah barang tentu akan mempengaruhi semakin banyaknya HaKI atas produk-produk temuan atau ciptaan. Hal ini menjadikan pertumbuhan industri suatu negara semakin tinggi dan aspek perdagangan menjadi bagian yang utama bagi peningkatan perekonomiannya. Tentunya negara maju akan memiliki

23 Masalahnya bukan sekadar pada bidang ekonomi saja, akan tetapi juga pada sumber daya yang merupakan pemain dalam globalisasi yang harus dikembangkan kemampuannya. Lihat dalam Gunarto Suhardi, "Globalisasi dan Sumberdaya Manusia ynag Kompetitif", Jurnal Hukum Pro Jusitia Vol. 25 No. 3 Juli 2007 FH Unpar Bandung, hlm. 190-197; Victor Purba, "Peranan Hukum dalam Global Kompetisi pada Era Globalisasi”, Majalah Hukum Pro Justitia Tahun XII No. 2 April 1994 FH Unpar Bandung, hlm. 56-62. keunggulan dalam aspek perdagangan, karena salah satu diantaranya ditentukan oleh keunggulan komparatif berupa kemajuan ilmu pengetahuan dan teknologinya, yang sangat berkaitan dengan masalah Hak atas Kekayaan Interlektual (HaKI).

\section{Penutup}

Simpulan

Hak atas Kekayaan Intelektual (HaKI) merupakan hak yang muncul melalui karya, karsa, cipta manusia karena kemampuan intelektualitas yang dimilikinya, dan juga merupakan hasil kegiatan berfikir kreatif manusia dalam mendeskripsikan suatu temuan atau ciptaannya yang ditujukan kepada masyarakat umum dalam berbagai bentuknya. Menurut World Intellectual Property Organization (WIPO), badan dunia di bawah naungan PBB, hak atas kekayaan intelektual terbagi menjadi 2 katagori, yaitu hak kekayaan industri, yang mencakup penemuan (paten), merek, desain industri, dan indikasi geografis, serta termasuk dalam katagori ini adalah rahasia dagang; dan hak cipta, yang termasuk dalam katagori ini adalah karya-karya literatur dan artistik, seperti novel, puisi, karya pangggung, film, musik, lukisan, fotografi dan patung.

Permasalahan HaKI merupakan suatu permasalahan yang terus berkembang sesuai dengan perkembangan ilmu pengetahuan dan teknologi. Permasalahan HaKI terus berkembang dengan maraknya pembajakan (piracy) terhadap produk yang dianggap laku di pasaran. Sebaliknya perkembangan ilmu pengetahuan dan teknologi juga memberikan pengaruh yang sangat besar terhadap permaslahan HaKI, sebagai contoh perkembangan di bidang bioteknologi, dengan adanya teknologi rekayasa genetika menyebabkan lahirnya kebutuhan untuk melindungi hasil rekayasa tersebut, hingga munculnya undang-undang tentang Perlindungan terhadap Varietas Tanaman (PVT.). Memasuki era globalisasi permasalahn HaKI semakin bertambah kompleks, tidak murni lagi hanya menyangkut bidang HaKI semata, akan tetapi sudah menyangkut bidang ekonomi antar negara. Sehingga HaKI sudah merupakan bagian 
terpenting bagi suatu negara untuk menjaga keunggulan industri dan perdagangannya dalam menumbuhkan perekonomiannya.

\section{Saran}

Perkembangan kehidupan yang berlangsung cepat, yang dibarengi dengan kemajuan ilmu pengetahuan dan teknologi, yang sangat mempengaruhi perindustrian dan perekonomian suatu negara, kiranya perlu adanya dorongan dalam memberikan perlindungan hukum yang semakin tegas dan semakin efektif terhadap HaKI.

Adanya Undang-Undang Tentang Hak atas Kekayaan Intelektual (HaKI), kiranya perlu adanya pemehaman mengenai HaKI bagi masyarakat umum, khususnya bagi aparat penegak hukum, sehingga apa yang ingin dicapai oleh undang-undang tersebut dapat terwujud. Di era global yang dibarengi dengan era digital atau cyber, kiranya perlu adanya database online system dalam kaitannya dengan pengajuan paten, persetujuan paten, dan permassalahan transaksi lainnya di Direktorat Paten.

\section{Daftar Pustaka}

Abdurrasyid, Priyatna. 2001. The Arbitration Law of Indonesia, dalam Prospek dan Pelaksanaan Arbitrase di Indonesia. Bandung: Citra Aditya Bakti;

Budiningsih, Catharina Ria. "Hak Desain Industri Vs Perlindungan Hukum pada Motif-motif Tradisional". Jurnal Hukum Pro Justitia Tahun 20 No. 1. Januari 2003. Bandung: FH Unpar;

Corriea, Carlos M. 2000. Intellectual Property Rights, the WTO and the Developing Countries: Third World Network. Penang;

Damian, Eddy. "Pengaturan dan Pengertian Hak Cipta Sebagai Hak Kekayaan Intelektual". Majalah Hukum Pro Justitia. Tahun 19 No. 3. Juli 2001. Bandung: FH Unpar;

Erawaty, AF Elly. "Sistem dan Mekanisme Perdagangan Internasional". Majalah Hukum Pro Justitia Tahun 12 No. 4 Oktober 1994. Bandung: FH Unpar Bandung;

Escudero, Sergio. 2001. International Protection of Geographical indications and Developing Countries, Trade Related Agen- da. Developing and Equity working paper. July 2001. South Centre;

Kabat, Soendari "Aspek Hukum Hak Atas Desain Tata Letak Sirkuit Terpadu”. Jurnal Hukum Pro Justitia Vol. 23 No. 2. April 2005. Bandung: FH Unpar;

Kesowo, Bambang. Pengantar Umum Mengenai Hak atas Kekayaan Intelektual (HaKl). Jakarta: Sekretariat Negara RI. (terbit tanpa tahun);

Margono, Suyud. 2010. Hukum Hak Cipta Indonesia. Bogor: Ghalia Indonesia;

Megan Richardson, et.al. 2000. The Benefits and cost of Copyrights: an Economic Perspective, Discussion Papers for The Centre for Copyright Studies Ltd. Published in June 2000;

Purba, A. Zen Umar. "Menyambut Millenium III: TRIPs, Dimensi HaKI dan Kesiapan Kita". Newsletter No.39. X (Desember 1999);

Purba, Victor. "Peranan Hukum dalam Global Kompetisi pada Era Globalisasi”. Majalah Hukum Pro Justitia. Tahun 12 No. 2. April 1994. Bandung: FH Unpar;

Purwaningsih, Endang. "Paten sebagai Konstruksi Hukum Perlindungan terhadap Invensi Bidang Teknologi dan Industri". Jurnal Hukum Pro Justitia. Vol. 24 No. 2. April 2006. Bandung: FH Unpar;

Purwoleksono, Didik Endro. "Tindak Pidana di Bidang Merek". Jurnal Yuridika Vol. 20 No. 4 Juli 2005. Surabaya: FH Unair;

Rahardjo, Satjipto. 1991. Ilmu Hukum. Bandung: Alumni;

Rahayu, Devi. "Perlindungan Hukum terhadap Hak Clpta Motif Batik Tanjungbumi Madura”. Jurnal Mimbar Hukum. Vol. 23 No. 1. Februari 2011. Yogyakarta: FH UGM;

Shidarta. "Beberapa Catatan tentang Pengaturan Indikasi Geografis dan Indikasi Asal dalam Hukum Merek Indonesia". Majalah HUkum Pro Justitia Tahun 16 No. 3 Juli 1998. Bandung: FH Unpar;

Suhardi, Gunarto. "Globalisasi dan Sumberdaya Manusia ynag Kompetitif". Jurnal Hukum Pro Jusitia. Vol. 25 No. 3. Juli 2007. Bandung: FH Unpar;

-..-.-.-. "Peran WTO dalam Pembentukan Peraturan Perdagangan Internasional". Jurnal Hukum Pro Justitia. Vol. 25 No. 1. Januari 2007. Bandung: FH Unpar; 
"Peran dan Arti Penting Perjanjian Lisensi dalam Melindungi Merek Terkenal". Jurnal Mimbar Hukum. Vol. 22 No. 1. Februari 2010. Yogyakarta: FH UGM;

Sujatmiko, Agung. "Prinsip Hukum Kontrak dalam Lisensi Merek". Jurnal Mimbar Hukum Vol. 20 No. 2 Juni 2008. Yogyakarta: FH UGM;

"Aspek Yuridis Lisensi Merek dan Persaingan Usaha". Jurnal Hukum Pro Justitia. Vol. 26 No. 2. April 2008. Bandung: FH Unpar;

. "Pembajakan Merek Merusak Perekononomian Nasional". Jurnal Hukum Pro Justitia Vol. 25 No. 3. Juli 2007. Bandung: FH Unpar;

-.-.-.-. "Politik Hukum Perlindungan Hak Merek". Majalah Hukum Pro Justitia tahun 19 No. 1. Januari 2001. Bandung: FH Unpar;

. "Perlindungan Hukum Hak Merek Secara Represif". Majalah Hukum Pro Justitia Tahun 19 No. 3. Juli 2001. Bandung: FH Unpar Bandung;
Supanto. "Kebijakan Hukum Pidana dalam Penanggulangan Pembajakan Perangkat Lunak Komputer". Jurnal Mimbar Hukum Vol. 19 No. 3. Oktober 2007. Yogyakarta: FH UGM;

Suradiyanto. "Perlindungan Hukum terhadap Produsen Ditinjau dari Segi Indikasi Geografis: Studi Kasus Produk Sarung Samarinda". Jurnal Hukum Pro Justitia. Vol. 24 No. 2. April 2006. Bandung: FH Unpar;

Utomo, Tomi Suryo. "Perkembangan Definisi Merek Pasca Perjanjian TRIPs dan Kemungkinan Perluasan Definisi Merek di Indonesia". Jurnal Ilmiah Hukum dan Dinamika Masyarakat. Edisi Khusus Agustus 2009. Semarang: FH Untag;

Wijoyo, Suparto. "GREAT SIGNIFICANCE" Hukum dalam Proses Alih Teknologi (Pendayagunaan Hukum sebagai Instruen Proses Alih Teknologi)". Majalah Hukum Pro Justitia Tahun 16 No. 3 Juli 1998. Bandung: FH Unpar. 